\title{
The Main Modernization Directions of the Industrial Complex
}

\author{
N.N. Belanova ${ }^{1}$, A.D. Kornilova $^{1}$, V.V. Mantulenko ${ }^{1, *}$ and $A . V$. Mantulenko $^{2}$ \\ *Corresponding author: mantoulenko@mail.ru \\ ${ }^{1}$ Samara State University of Economics, Samara, Russia, \\ ${ }^{2}$ Samara University, Samara, Russia
}

\begin{abstract}
The functioning of enterprises in the conditions of economic uncertainty and high risks associated with it, dependence on external economic conjuncture, low competitiveness of domestic goods and services of Russia give determine a range of problems that can be solved only through modernization reforms in industry. They are determined by the formation of a competitive type of industrial production in Russia and high-tech industries that are able to generate high technology and modernize the sectoral system of national reproduction. Modernization of the Russian industry is based on internal growth factors using modern technologies and business methods with a gradual increase of the innovation potential.

The purpose of the study is to identify the main directions of modernization for the formation of a modern competitive industry as the basis for ensuring economic growth and improving the quality of life of the population. To achieve this goal, the authors used dialectical, system-functional, economic-statistical, and formal-logical methods.

In this contribution, the authors summarized the main directions of the implementation of industrial policy, presented statistical data on the creation of industrial parks. To strengthen the industrial potential of the Russian economy, it is necessary to provide conditions for the development of modern production, increasing production and energy efficiency, and increasing investment in fixed assets. The authors developed measures for the modernization of the industrial complex and predicted results of this program. Among key activities there are the development of affordable investment and innovation infrastructure, the creation of industrial parks and the development of the institutional environment.
\end{abstract}

Keywords: industry, industrial complex, industrial enterprises, modernization, innovative development.

\section{Introduction}

Situations occurring in recent years in the global economy have led to a number of difficulties that faced the domestic industry. The main problems are associated with the purchase of imported raw materials, components and equipment, with timely transfer of Western technologies and the development of successful cooperation with foreign partners and investors. Sanctions imposed by Western countries affected a large number of Russian enterprises. Enterprises of the industrial complex are faced with the need to survive in the difficult conditions as well as to carry out strategic changes in the structure of production. The current situation has already led to changes in organizational and management methods and principles in solving production problems.

One of the most important problems is the problem of modernization of the domestic industrial complex. This process is multifaceted: having a complex nature of technological and infrastructural changes it is implemented in enterprises with the aim of qualitative transformations in the industry and the creation of high-tech innovative assets.

Many economists studied problems of modernization regarding the influence of internal and external challenges [15], the creation of necessary conditions for modernization and economic growth [6-10]. Some economists studied econometric methods for analyzing factors [11] and models [12-14] of modernization. Special attention was paid to problems of financing and investment $[15,16]$. When considering the problems of modernization, certain results were obtained in the world theory and practice: theoretical foundations were developed, conceptual approaches were substantiated. At the same time, the main aspects of the theory and practice of modernization need additional research: classifications, mechanisms and methods for its implementation in the conditions of depressive foreign economic conditions have not been worked out properly.

\section{Problem Statement}

Awareness of the necessity and urgency of modernizing the Russian industry is one side that allows us to solve a lot of problems in the Russian economy. The other side is the creation of conditions under which this task will be solved.

Modernization of the industry is necessary for the transition of the Russian economy to the trajectory of sustainable development. As practice shows, economic evolution occurs through the introduction of innovations and changes in technology. 


\section{Research Questions}

To develop and implement directions of industrial modernization, it is necessary to solve a set of tasks:

- to consider general trends in the functioning and development of the Russian industry;

- to justify the need for structural changes in the industrial complex;

- to identify the main problems faced by industrial enterprises and industry complexes;

- to consider measures that promote modernization in order to form a modern competitive industry.

\section{Purpose of the Study}

The purpose of the study is the identification of directions for modernization of the Russian industry and formation of a modern competitive industrial complex. These directions should serve as the basis for ensuring economic growth and improving the quality of life of the population.

\section{Research Methods}

The methodological basis of the study consists of fundamental principles of the economic theory, including scientific works of Russian and foreign scientists in the field of industrial economics as well as results of statistical studies in the field of functioning of industrial sectors of Russia and in other countries.

To date, certain methods and trends in innovative development have emerged in the economic science. However, to identify areas of modernization of the industrial complex of the country requires an integrated approach. In this study, the authors used dialectic, system-functional, economic-statistical, and formal-logical methods.

\section{Findings}

Without industrial modernization, it is impossible to achieve high efficiency and competitiveness of the Russian economy. First, the profound technological backwardness and depreciation of the technical and technological base of the industry makes it impossible to use the available production resources efficiently. According to official data, the depreciation of fixed assets in the Russian industry exceeds $70 \%$ and outdated technologies are used by $93 \%$ of manufacturing enterprises. It is also shown in the research results of labor productivity in the Russian economy conducted by McKinsey \& Company: on the average, it does not exceed 33\% of the US level in the industry, and the lowest level is fixed in the electric power industry (15\% of the US level). The GDP energy intensity in Russia is $1.5-2$ times higher than in developed countries. If in Norway, Sweden, Finland $160 \mathrm{~kg}$ of oil are spent on a thousand dollars of GDP, in France, Spain and Italy - 80-100 kg, and in Russia it is almost $500 \mathrm{~kg}$ [2].

Secondly, the material consumption of Russian products is unreasonably high, on the average it is $30 \%$ more than this indicator in developed countries. This circumstance gives a steady increase in the production of material resources within which around $75 \%$ of basic production assets and more than $45 \%$ of labor resources are involved in our country [17].

Thirdly, in these circumstances, it is impossible to update the product line timely. Production using new technologies is about 70 billion rubles, and its share in the total industrial output is $0.6 \%$. This is significantly less than in most European countries: the share of fundamentally new products in the industry is on the average 17\% in Finland, $15 \%$ in Sweden, 10-11\% in Germany, France, and the UK [18].

The high cost and obsolete product range weaken the competitive position of Russian producers both in foreign and domestic markets. Overcoming this problem requires radical improvement of the existing productive forces of the country, on the basis of their technical re-equipment and expansion of the high technologies usage.

Since the implementation of modernization reforms in the industry requires the concentration of resources and other opportunities of the economy and society, this task cannot be done without the active participation of government bodies. Moreover, the participation of the state on all levels should be characterized by interest in a positive result, soundness and consistency of the made decisions.

\subsection{General directions of industrial policy implementation}

For the period from 2012 to 2018, the number of industrial parks (new ones and already existing) increased by more than 2.5 times: from 64 to 166 on the territory of the Russian Federation. Their geography continues to expand: in 2012 they were in 27 regions, and in 2018 - already in 51 regions. The total area of industrial parks increased from 14,315 to 23,572 hectares, while the number of residents in the existing parks increased by 2.6 times and exceeded 2.5 thousand companies. The number of new created workplaces increased by more than 3 times: from 45 thousand to 146 thousand. $10 \%$ of residents of the industrial parks are foreign companies from 27 countries (more than 80 are from Germany, more than 40 are from the USA, more than 20 are from Japan). As for industrial technoparks, their legislative definition and state support for such facilities began in 2014, since then, the number of operating structures doubled and reached 
45 facilities in 22 regions. On their territory, there are 3,156 companies operating in the high-tech industrial sectors: instrument making, electronics, laser technology, chemical and medical industry, biotechnology and new materials [17].

\subsection{Objectives of strengthening the industrial potential}

In order to strengthen the industrial potential of the Russian economy, increase the gross product and the number of workplaces in the country, it is necessary to solve a number of important tasks:

- creation of conditions in the civil industries for development of enterprises which are competitive in the Russian and world markets, equipped with modern production technologies;

- creation of conditions in the sectoral structure of industry for development of modern enterprises that produce goods with high added value;

- increase of the modern innovative production;

- support of the positive dynamics of investments in fixed assets;

- significant reduction in the dependence of the Russian economy on imports of products, equipment and technologies that are critically important for the sustainable development, ensuring the implementation of import substitution plans in industries;

- modernization of the technological base of industries focused on investment demand (engineering, machine tool industry, etc.);

- ensuring a significant amount of extrabudgetary investments in the renewal of fixed assets and increase in production capacity;

- formation of the potential of the Russian Federation in the world markets by increasing production efficiency and energy efficiency;

- ensuring the growth of labor productivity through the use of advanced technologies and modern equipment;

- ensuring substantial, outpacing (in relation to other sectors of the economy) productivity growth through investment in fixed assets of industry;

- increase in the number of high-performance workplaces by creating new industries;

- creation of complete infrastructure, including pilot, pilot industrial, industrial enterprises, engineering companies and centers for the development of technologies for the application of innovative products and technologies;

- formation of an effective system to support the demand for products of new industries;

- creation of new workplaces in industries requiring highly qualified personnel;

- ensuring the necessary for sustainable development of the economy intensity of expenditures on research in civil industries, both from budgetary and extra-budgetary sources;

-application of modern national standards and measuring instruments to increase the competitiveness of domestic products and promote domestic innovative products and technologies to world markets;

-technological renewal of the industry and the introduction of the best available technologies to significant reduction of energy intensity of the most energy-intensive industries and to produce modern environmentally friendly products.

\subsection{Industry Modernization Activities}

Modernization should be begun in the traditional industrial enterprises which form the basis of the country's economy. However, modernization options depend on many factors:

- the degree of the influence of external economic factors on the economic efficiency of industrial enterprises;

- the dynamics of the industrial sectors development;

- the degree of efficiency and intensity of government support measures to ensure the sustainable development of industrial enterprises.

According to the modernization goals, industrial enterprises should become not only the basis of the functional growth, ensuring the growth of competitive products, but also the basics of the institutional growth that support the development of innovation activities (Figure 1). 


\begin{tabular}{|c|c|}
\hline \multicolumn{2}{|c|}{ Modernization of the Industrial Complex } \\
\hline Activities & Results \\
\hline $\begin{array}{l}\text { 1. Creation of industrial parks. } \\
\text { 2. Creation of the infrastructure for } \\
\text { the existing industrial parks. } \\
\text { 3. Reconstruction and modernization } \\
\text { of industrial equipment. } \\
\text { 4. Mastering the components for the } \\
\text { technology-saving industry. } \\
\text { 5. Development of the innovation } \\
\text { infrastructure. } \\
\text { 6. Development of the affordable } \\
\text { investment infrastructure. } \\
\text { 7. Development of the institutional } \\
\text { environment and increasing the } \\
\text { efficiency of state bodies. } \\
\text { 8. Creation of a scientific educational } \\
\text { and technical innovation complex. } \\
\text { 9. Development of core networks of } \\
\text { regional integrated structures. } \\
\text { 10. Creation of information and } \\
\text { telecommunication network of } \\
\text { authorities. }\end{array}$ & $\begin{array}{l}\text { 1. Improving efficiency and } \\
\text { transparency in the management of } \\
\text { industrial enterprises. } \\
\text { 2. Improving the image and } \\
\text { reputation of industrial enterprises. } \\
\text { 3. Increasing the share of the } \\
\text { domestic market for industrial } \\
\text { products. } \\
\text { 4. Entry into international markets. } \\
\text { 5. Improving the efficiency of } \\
\text { management decisions. } \\
6 \text {. Ensuring the effectiveness of the } \\
\text { information exchange between } \\
\text { enterprises. } \\
\text { 7. Implementation of best practices } \\
\text { and improvement of production } \\
\text { activities. } \\
\text { 8. Improving the product quality and } \\
\text { competitiveness of industrial } \\
\text { enterprises. } \\
\text { 9. Improving the competence of } \\
\text { personnel of industrial enterprises. } \\
\text { 10. Efficient provision and allocation } \\
\text { of resources. }\end{array}$ \\
\hline
\end{tabular}

Figure. 1. Directions of modernization of the industrial complex (Source: compiled by the authors)

To implement the modernization, it is necessary to carry out a technological reconstruction of the main industrial enterprises which will later become the mainstay of the entire industrial complex. A prerequisite for the effective modernization of the Russian industry is multi-state government support based on the formation and implementation of state-owned innovative projects in the priority areas.

\section{Conclusion}

It is impossible to solve social problems and ensure the economic and technological security of the country without modernization. The transition of the industry to the production of new competitive products, the use of modern resourcesaving technologies will entail an increase in the incomes of industrial enterprises and the state budget that in turn will create additional opportunities for the implementation of important social projects. Expansion of production will increase the share of value added and, consequently, the level of remuneration of employees as well as the size of accumulated investment resources. New workplaces will be created, focused on highly skilled labor, and this will make the growth of the educational level in the country in demand. The new level of industrial development will allow not only to solve the problem of overcoming the investment dependence of the Russian economy, but also to increase its product and technological security.

\section{References}

1. A. Flanders, Collective bargaining: A theoretical analysis. British Journal Of Industrial Relations. 6(1), 1-26. URL: https://onlinelibrary.wiley.com/doi/pdf/10.1111/j.1467-8543.1968.tb00526.x (1968).

2. S. Kiselev, S. Solghenitsyn, Effective resource management. McKinsey Bulletin: Management Theory and Practice, 27. URL: http://www.vestnikmckinsey.ru/introduction/ehffektivnoe-upravlenie-resursami [in Rus.] (2013).

3. N.I. Komkov, External and internal challenges and prospects for the modernization of the Russian economy. WORLD (Modernization. Innovations. Development), 9(1). 12-24. URL: https://cyberleninka.ru/article/v/vneshniei-vnutrennie-vyzovy-i-perspektivy-modernizatsii-rossiyskoy-ekonomiki [in Rus.] (2018). 
4. B.V. Kuznetsov, Essays on the modernization of the Russian industry: Behavior of firms. Moscow: Publishing house of the Higher School of Economics. URL: https://id.hse.ru/books/111061023.html [in Rus.] (2014).

5. D. Otobo, Industrial Relations: Theories and Controversies. Lagos: Salama Press (2000).

6. L.M. Borsch, S.V. Gerasimova, A.S. Tyulin, On the issues of economic transformation and modernization of technological processes in Russia. Journal of Creative Economy, 12(6), 717-732. DOI: 10.18334 / ce.12.6.39206 [in Rus.] (2018).

7. A.P. Garnov, V.Yu. Garnova, Modernization of the Russian economy. Bulletin of the Plekhanov Russian University of Economics, 3, 72-77. URL: https://vest.rea.ru/jour/article/view/160/160. [in Rus.] (2016).

8. T.D. Kirtadze, Electronic industry as the basis of neo-industrial modernization. Journal of Creative Economy, 3, 387398. DOI: 10.18334 / ce.11.3.37699 [in Rus.] (2017).

9. B.N. Porfiriev (Ed.), Modernization of industry and the development of high-tech industries in the context of "green growth". Moscow: Scientific Consultant [in Rus.] (2017).

10. V.P. Zolotareva, The military-industrial sector as a factor in the modernization of the economies of the "catchingup" countries. Russian entrepreneurship, 17(12), 1483-1496. DOI: 10.18334 / rp.17.12.35392. URL: https://cyberleninka.ru/article/v/voenno-promyshlennyy-sektor-kak-faktor-modernizatsii-ekonomik-strandogonyayuschego-razvitiya [in Rus.] (2016).

11. A. Abelian, N. Ivanova, Management of profile factors of industrial enterprises modernization. Scientific Herald of the Southern Institute of Management, 4, 4-9. URL: https://doi.org/10.31775/2305-3100-2017-4-4-9 [in Rus.] (2017).

12. P. Ackers, A. Wilkinson, British industrial relations paradigm: A critical outline history and prognosis. Journal of Industrial Relations, 47(4), 443-456. URL: https://doi.org/10.1111\%2Fj.1472-9296.2005.00184.x (2005).

13. S. Glinkin (Ed.), Modernization in the countries of the Russian neighborhood belt: Structural and technological aspects. Moscow: Nestor-History (2012).

14. S. Huntington, The clash of civilizations and the remaking of world order. New York, N.Y.: Simon \& Schuster (2011).

15. Alekseev, A.V. Modernization of the Russian economy: Who will pay the bill. ECO (All-Russian Economic Journal), 1, 74-86. URL: http://www.old.ecotrends.ru/archive/673-edition-01/2092-2015-01-alekseev [in Rus.] (2015).

16. O.N. Kolomyts, Foreign direct investment as a necessary condition for the modernization of the Russian economy. International Research Journal, 2(33/3), 41-42. URL: https://research-journal.org/economical/pryamyeinostrannye-investicii-kak-neobxodimoe-uslovie-modernizacii-rossijskoj-ekonomiki/ [in Rus.] (2015).

17. The official website of the Russian Ministry of Industry and Trade. URL: http: //minpromtorg.gov.ru/ (2019).

18. Federal State Statistics Service. URL: http://www.gks.ru/ (2019). 